\title{
Die ou-Kersaandgesprek van Friedrich Schleiermacher in Afrikaans: Agtergrond, vertaling en hermeneutiek
}

\author{
Andries van Aarde \\ Departement Nuwe-Testamentiese Wetenskap \\ Universiteit van Pretoria
}

\begin{abstract}
The Christmas Eve Dialogue of Friedrich Schleiermacher in Afrikaans: Background, translation and hermeneutics

In his Christmas Eve Dialogue (Die Weinachtsfeier: Ein Gespräch), Schleiermacher reflected on the theological tension between the quest for the historical Jesus and the dogma of the incarnation of Christ as "true God" and "true human". In the fashion of his Romantic contemporaries, Schleiermacher presented his theology in the form of a story about friends celebrating Christmas Eve and their thoughts on the meaning of Jesus' birth in their lives. This story was written in 1805 and printed in Gothic German in 1843. The aim of this article (the first of a series) is to translate Schleiermacher's Christmas Eve Dialogue in Afrikaans. This article gives a brief biographical overview of Schleiermacher's life and discusses the theoretical premises of his hermeneutics. After the translation of the first part of the Christmas Eve Dialogue (pages 465-472 in the 1843 printed edition), the article concludes with an explanation of the reasons why he would write such a story.
\end{abstract}

Die in den Monologen entwickelte Anschauung, dass es Freiheit und Unendlichkeit nur in der Übernahme des menschlichen Daseins in seiner Endlichkeit und Zeitlichkeit geben kann, wird in der Weihnachtsfeier in seiner theologischen Voraussetzung deutlich. Aus der Angewiesenheit des Menschen auf Erlösung und Heil heraus legt Schleiermacher seine christologische Konzeption dar, die - aus den Grenzen theologischer Begriffsbildung befreit - besagt, dass in Christus der Mensch an sich oder das Urbild des wahren Menschen geschichtliches Ereignis geworden ist.

(Hertel 1965:205) 
Protestant liberalism has often been charged with reducing the historical Jesus to a moral and spiritual example or hero, in contrast to the one who saves lost [hu]mankind by his sacrifice. Schleiermacher's Christ, however, does not just serve as a spur to moral endeavour. His opening christological thesis runs: "If the spontaneity of the new corporate life is original in the Redeemer and proceeds from him alone, then as an historical individual he must have been at the same time ideal (i.e. the ideal must have been completely historical in him), and each historical moment of his experience must at the same time have borne within the ideal" [Schleiermacher [[1830]] 1928:377]. The new life is not generated by the believer, or by the community itself, but is actually imparted through communion with the Jesus in whom it has its source and who is its "ideal realization". It must be noted, however, that when Schleiermacher speaks of "ideality" (Urbildlichkeit) he does not mean an abstract model of perfection, but something nearer the Platonic "form", that which actually imparts reality to a particular object which participates in it. Also, while Schleiermacher speaks of the "exemplary" status of Jesus (Vorbildlichkeit) he does not mean a kind of model to be copied, but rather the way in which Jesus himself exemplified the human race by solidarity with it in the fullness of humanity (my emphasis).

(Clements 1987: 54-55)

\section{SITZ IM LEBEN}

Friedrich Daniel Ernst Schleiermacher is op 21 November 1768 in Breslau gebore en is op ses en sestigjarige ouderdom op 22 Februarie 1834 in Berlyn dood. Volgens Leopold von Ranke (kyk Barth 1982:3) het tussen 20 en 30 duisend mense die begrafnis bygewoon.

Gedurende die periode $1796-1802$ is hy predikant in die Charite-Hospitaal in Berlyn. Vanuit hierdie posisie begin hy om 'n enorme invloed uit te oefen op die godsdienstige en intellektuele, kuns- en musiekgemeenkap van die Pruisiese hoofstad. Hy kritiseer skerp die "godsdiensveragters" onder die intelligentsia in sy werk Über die Religion: Reden an die Gebildeten unter ihren Verachtern ([1799] 1958). Hy vertaal die dialoë van Plato en die vertaalprojek beïnvloed sy later hermeneutiese denke op 'n besondere wyse (vgl Brandt 1941:6, 16). In 1802 verlaat hy Berlyn en word predikant in die Hofkerk in Stolpe, Pomeranië. 
In 1804 word Schleiermacher aangestel as professor in die teologie aan die Universiteit van Halle. Hy doseer veral hermeneutiek, etiek en filosofiese dialektiek (Brandt 1941:22-41). Schleiermacher is veral entoesiasties oor die hermeneutiek en kan bestempel word as die doyen van die studie van die vak hermeneutiek aan 'n universiteit (kyk Kimmerle [1977] 1986:21-40). So byvoorbeeld, hoewel Wilhelm Dilthey (1924:330; vgl Gadamer 1972:250-290) die eerste persoon was wat die term "hermeneutiese sirkel" gemunt het, het die saak waarom dit in hierdie begrip gaan, sentraal in Schleiermacher se hermeneutiese program gefunksioneer (Kimmerle 1986:6). In Halle is Schleirmacher steeds as prediker aktief en is sterk betrokke by kerklike belange (vgl Streetman 1988:2). Dit wil voorkom asof hy in Halle in 1805 sy ou-Kersaandgesprek, getitel Die Weinachtsfeier: Ein Gespräch, publiseer (kyk Schleiermacher 1843:461-525). Hierdie werk handel oor die inkarnasie van Christus en dit bevat belangrike riglyne om sy belangrike werk Der christliche Glaube nach den Grundsätzen der evangelischen Kirche im Zusammenhänge dargestelt (1821-1822 - 'n hersiene Duitse uitgawe verskyn in 1830 en 'n Engelse vertaling [kyk literatuurverwysingslys] in 1928) te verstaan.

In 1806 val Napoleon Pruise in en verwoes Halle. Na die inname van Halle keer Schleiermacher na Berlyn terug. In 1808 open die Universiteit van Berlyn. Schleiermacher word in 1810 aangestel as die dekaan van die teologiese fakulteit. In 1815 dien hy as rektor. Hy speel 'n leidinggewende rol in die universiteitswese as deel van die program van die Pruisiese hernuwing onder Wilhelm von Humboldt. Schleiermacher trou in 1809 met Henriette von Willich. Hy word in dieselfde jaar predikant van die bekende Triniteitskerk in Berlyn en preke wat hier gelewer word, word beroemd oor die hele Duitsland (vgl Barth 1972:430). Sy gepubliseerde preke bevat meer as een-derde van sy versamelde werke. Schleiermacher het sy laaste groot preek op Sondag 26 Januarie 1834 gehou en sy laaste oggendoordenking op 2 Februarie. Hy het sy laaste lesing gehou op Donderdag 6 Februarie en siek geword op Vrydag die 7de en gesterf op Woensdag 22 Februarie 1834. Op sy sterfbed dring hy aan om saam met sy familie Nagmaal te vier (Barth [1952] 1972:432). 
Schleiermacher se werke bestaan uit selfstandige monografiee, lesings, preke, vertalings, briefwisselings en biografiese dokumente. ${ }^{1}$

\section{SCHLEIERMACHER SE HERMENEUTIEK}

\subsection{Die begrip "hermeneutiek"}

Schleiermacher se hermeneutiese program word bepaal deur sowel sy verstaan van die begrip"hermeneutiek" as die onderskeid wat hy tref tussen die begrippe "dialektiek" en "hermeneutiek". Op grond van Schleiermacher se werk, Hermeneutik und Kritik: Mit einem Anhang sprachphilosophischer Texte Schleiermachers (herdruk in 1977 en redaksioneel verwerk in 1992 deur M Frank), asook Dilthey (1924) se bydrae "Die Entstehung der Hermeneutik", die werke van Brandt (1941), Palmer (1969), Kimmerle (1986), en Müller-Vollmer (1992), kan sy verstaan van die begrip "hermeneutiek" soos volg saamgevat word:

- hermeneutiek is so universeel as taal;

- hermeneutiek is nie beperk tot die uitleg van die Bybel of antieke geskrifte nie;

${ }^{1}$ Verwysings na Schleiermacher se werke het tot aan die begin van die tagtigerjare gekom uit die ou Sämmtlichen Werke wat in vele opsigte onvolledig en vir die meeste navorsers ontoeganklik is. Die nuwe projek Friedrich Schleiermacher Kritische Gesamtsausgabe word deur De Gruyter in Berlyn uitgegee en Band 1 (609 bladsye) het in 1984 vrskyn en Band 7 (Teilband 1 beslaan 357 bladsye en Teilband 2 uit 409 bladsye) in 1980 en 1984 (Teilband 3 wat uit 672 bladsye beslaan). Hierdie Kritische Gesamtsausgabe word uitgegee onder redakteurskap van Hans-Joachim Birkner, Gerhard Ebeling, Hermann Fischer, Heinz Kimmerle en Kurt-Victor Selge. Dertien bande word beplan:

- Jugendschriften 1787-1796

- $\quad$ Schriften aus der Berliner Zeit 1796-1799

- $\quad$ Schriften aus der Berliner Zeit 1800-1802

- $\quad$ Schriften aus der Stolper Zeit (1802-1804)

- Schriften aus der Hallenser Zeit (1804-1807)

- Schriften aus der Berliner Zeit (1804-1834)

- Universitätsschriften. Kurze Darstellung des theologischen Studiums, 1. und 2.Auflage

- Der christliche Glaube, 1.Auflage

- Exegetische Schriften

- Kirchenpolitischen Schriften

- Theologisch-dogmatisch Abhändlungen

- Akademieabhändlungen und verschiedene Schriften über die Religion, 4.Auflage

- Der christliche Glaube, 2.Auflage. 
- hermeneutiek is nie net 'n teologiese aangeleentheid nie;

- hermeneutiek het met taal en kultuur as sodanig te doen en nie net met 'n gedeelte daarvan nie;

- hermeneutiek is geleë op die kommunikasie-as (wat deur Dilthey die "hermeneutiese sirkel" genoem is) tussen vreemdheid en vertroudheid, tussen onwetendheid en bekendheid;

- hermeneutiek gee voorkeur aan gesproke taal as uitdrukking van iemand se hele lewe.

Die onderskeid wat hy tref tussen die begrippe "dialektiek" en "hermeneutiek" kan weer met die volgende kort gedagtes saamgevat word:

Dialektiek is die teorie oor die tot woorde bring van gedagtes (in aansluiting by Immanuel Kant se "praktiese rede") en hermeneutiek is die tot gedagtes bring van woorde (in aansluiting by Kant se "teoretiese rede"). Daarom kan dialektiek gesien word as die teoreriese refleksie op die "beginsels van gesprek". Gesprek word gemotiveer deur die moontlike "eenheidwording" van gespreksgenote deurdat verskille opgehef word. Kommunikasie veronderstel die vervanging van vreemdheid met vertroudheid, dit wil sê onkunde word met kennis vervang. Dialektiek gaan egter nie van die aanname uit dat "absolute kennis" die ideaal van "eenheid van denke" is nie, maar van 'n "onoplosbare relatiwiteit". Met ander woorde, "alles is relasioneel tot alles". 2

Spanning is inherent aan enige dinkproses omdat die dinge waaroor gereflekteer word, uiteraard van mekaar verskil en tog met mekaar in verband gebring word. Die proses van denke is om vreemdheid met vertroudheid te vervang. Dit is dus die spanning wat daar tussen "objekte" bestaan, wat denke in

${ }^{2}$ Die ontkenning van "absolute kennis" hoef egter nie tot skeptisisme aanleiding te gee nie. Inteendeel, Immanuel Kant het dit beklemtoon dat kennispositiwisme op "dogmatisme" neerkom, en juis die ondermyning hiervan ruimte vir "geloof" skep. Horner \& Westacott (2000:22) verwys soos volg hierna: "The Critique of Pure Reason this contains a profound critique of what Kant calls speculative or transcendent metaphysics, the kind that aims at proving claims about the nature of God, the soul, free will or the reality that lies behind the world we experience. The empiricists were right, Kant says, we cannot have knowledge of such things. Knowledge is what science gives us, and that relates only to world we perceive with our senses. However, Kant argues also that this world cannot be thought of as 'ultimate reality'. It is the world as it appears to us, and therefore a world of appearances only. So neither science nor metaphysics can give us knowledge of ultimate reality. This leaves a space open for us to have faith that those beliefs that provide the underpinnings to morality - such as the belief that we are free and responsible, or the belief that there is some sort of cosmic justice to ensure that virtue will eventually be rewarded - are true." 
beweging bring. Daarom is, naas die "ideaal van eenheid van denke", kontras, teenoorgesteldes, die posisie van die "ander", deel van die proses van denke.

Syn (identiteit) is in die proses van denke "leeg" en word eers bepaal in "gesprek met ander". ${ }^{3}$ Die "identiteit van syn" word in gesprek bewerkstellig. Omdat daar in gesprek altyd beweeg word tussen identiteit en verskil en "absolute kennis" onmoontlik is - absolute identiteit vanweë die altyd teenwoordige teenstellings nooit bereik kan word nie - het kennis ' $n$ "onoorwinlike voorlopigheid".

Taal is die medium van denke. Dit is 'n individu wat taal gebruik, maar taal veronderstel gemeenskaplikeid, universaliteit. Enersyds skep taal onderskeidings as gevolg van individualisering (die gespreksgenote is immers aparte individue) en andersyds universaliseer taal in soverre dit gemeenskaplike taal is (gespreksgenote wil immers mekaar verstaan). In hierdie proses het dialektiek hermeneutiek nodig en omgekeerd, omdat hermeneutiek die woorde van individue tot gedagtes bring en dialektiek die gedagtes tot individue se woorde herlei.

Dialektiek en hermeneutiek het nie net met gesproke taal te doen nie, maar ook met tekste. Tekste is die resultaat van denke wat in woorde geformuleer is. Die universaliteit van denke verkry 'n empiriese individuele vorm in 'n teks. Dit beteken dat die teks tot in 'n hoë mate deur die individualiteit van die teks bepaal word. Niemand dink "korrek" sonder om verstaanbaar te wil wees nie. Denke word gemeenskaplik en volledig as dit kommunikeerbaar is en daarom is die "ander", die leser, die interpreteerder, reeds aanwesig in die skep van die teks, omdat 'n skrywer sigself rig op die verstaan deur 'n leser.

Dialektiek en hermeneutiek staan relasioneel tot mekaar as "tekskonstitusie" en "teksinterpretasie". Die kuns van gesprekvoering (dialektiek) en die kuns om te verstaan (hermeneutiek) impliseer mekaar wedersyds. Die beweging vanaf die universele na die individuele en vanaf die individuele na die

${ }^{3}$ Hierdie insig is onder andere deur Heidegger (en later deur filosowe soos Ricoeur, Derrida, Adorno en Levinas) uitgebou. Heidegger (in Collins \& Selina [1999] 2001:63) bring dit in verband met wat hy as die "outentieke identiteit" van mens-wees beskryf wat nie in Sein nie, maar in Dasein verwerklik word. Dasein is om in relasie met Ander te wees; mens-wees is om "ek-metander" te wees. 
universele is ' $n$ interaksie wat nie in abstrakte vakuum geskied nie, maar as 'n "historiese" proses (wat ook "fiktief" in 'n novelle ver-beeld kan word).

Die bereikte "identiteit van kennis", dit wil sê wanneer daar op grond van gesprek deur 'n deelnemer of gesamentlik deur die gespreksgenote gesê word dat daar tot verstaan en ooreenstemming gekom is, is egter altyd gedeeltelik. Verstaan is nie volledig nie, omdat so 'n "eenheid van kennis" as gevolg van die taligheid van denke (tekstualiteit en die verbale karakter van denke) nooit werklik alle teenstellings en individualiteit kan ophef nie.

\subsection{Die begrip "divinatoriese verstaan"}

Die bedoeling van die hermeneutiese program is dus om ' $n$ bepaalde soort "sekerheid" te verkry, sodat misverstande in 'n proses wat as "taligheid" beskryf word, opgelos kan word. Dit is 'n soort sekerheid wat iemand kry deur die bedoelde gedagtes (vanuit historiese perspektief kan 'n mens sê die waarskynlik "oorspronklike" bedoeling) van 'n outeur of spreker te rekonstrueer.

Schleiermacher verwys hierna as "divinatoriese sekerheid". Met hierdie uitdrukking het hy 'n "gissende", dit wil sê 'n vermoedende soort sekerheid in gedagte. Die Engelse woord to divine ("om te gis") is daarom 'n geskikte vertaalekwivalent vir die Duitse "divinatorisch".

Divinatoriese sekerheid staan teenoor "demonstratiewe sekerheid". Op grond van hierdie onderskeid onderskei Schleiermacher tussen "grammatikale hermeneutiek" en "psigologiese hermeneutiek". Laasgenoemde het nie iets met sielkunde as wetenskaplike dissipline te doen nie en ook nie met die bedoeling om "in mense se kop te kom om agter te kom wat hulle opinie sou wees nie". Die "grammatikale hermeneutiek" bestudeer taal en geskiedenis (die objektiverende gerigtheid van eksegese). Die woord "psigologiese" is afgelei van die Griekse woord భuxń wat met die uitdrukkings "self", "innerlikheid", "waaragtigheid", "outentieke bestaan" (of in Heidegger se terme met "Dasein") vertaal kan word. "Psigologiese verstaan" wil uitkom by die "identiteit van syn" (dit wil sê Dasein) van die interpreteerder en die geïnterpreteerde. Hierdie uitdrukking, "identiteit van syn", wat vroeër hierbo gebruik is toe gesê is dat dit op grond van gesprek 
(die proses wat as "taligheid" beskryf is) bewerkstellig word, is daarom nou weer ter sake. "Psigologiese hermeneutiek" bestudeer taal as uitdrukking van die "persoonlike lewe" (die sogenaamde subjektiewe gerigtheid) - gevoelens - van die deelnemers in die proses van kommunikasie.

Die onderskeid tussen "grammmatikale hermeneutiek" en "psigologiese hermeneutiek" is nie dieselfde as die verdeling tussen "demonstratiewe sekerheid" en "divinatoriese sekerheid" nie. Beide soorte sekerheid kom in sowel die "grammatikale" as die "psigologiese" hermeneutiek voor. "Demonstratiewe sekerheid" word verkry deur 'n vergelykende metode waardeur die interpreteerder die bekende en vertroude in verband bring met die onbekende en vreemde - 'n hermeneutiese sirkelproses wat poog om dele in die geheel met mekaar in verband te bring, of te wel die verlede met die hede, of te wel die onbekende met die bekende - en wat later die "hermeneutiese sirkel" genoem is. Op grond van so 'n proses van verstaan word die onbekende al hoe meer uitgeskakel (die sogenoemde "demonstratiewe sekerheid"), maar nie geheel en al nie, sodat verklaring steeds nodig is deur middel van gis en vermoede (die "divinatoriese sekerheid"). Deur middel van die "demonstratiewe" metode word gepoog om by die ideaal van universaliteit uit te kom en deur middel van die "divinatoriese" metode probeer die interpreteerder om by die individualiteit van die ander (die "identiteit van syn", of te wel outentisiteit, of te wel Dasein) uit te kom.

Die belang van die "divinatoriese" metode hou verband met die feit dat denke nooit sonder woorde plaasvind nie. Die feit dat denke (universeel) in woorde (historiese individualiteit) geskied, maak die gebruik van beide metodes noodsaaklik. Denke en woorde vorm 'n hermeneutiese sirkel. Elke woord word alleen begryp as 'n deel van 'n geheel, elke hoofstuk binne 'n werk as geheel. Die geheel moet geken word van waaruit die afsonderlike deel begryp kan word. Daarom is daar altyd sprake van onsekerhede en word alleen voorlopige konklusies bereik. Dit is 'n aanhoudende proses van heen en weer beweeg tussen deel en geheel en solank die geheel van die betekenis van 'n teks nie 
gesnap word nie, is gissende antisipasie nodig, dit wil sê "divinatoriese sekerheid" impliseer "demonstratiewe sekerheid" en omgekeerd.

\subsection{Die uitdrukking "gevoel van absolute afhanklikheid" ("schlechthinnige Abhangigkeit")}

Deur die Bybel (of enige ander teks) as 'n taalgebeure aan slegs die "grammatikale hermeneutiek" te onderwerp word die geloofseksistensie van die mens nie ontsluit nie; "psigologiese hermeneutiek" is ook nodig. Godsdienstige taal getuig van 'n gottglaubige Selbstbewußtsein. Die onmoontlikheid van "absolute kennis" hou verband met die beperktheid van die mens, van die mens se eindigheid, van die mens se gebondenheid aan die geskiedenis. Hierdie beperktheid, die eindigheid/begrensdheid van die menslike subjek, kom neer op die feit dat die mens nie oneindig eksisteer nie, nie sigself kan skep nie en derhalwe die onmiddellike bewussyn van absolute afhanklikheid van beperktheid aanvoel - 'n gevoel van gebrek aan vryheid, 'n uitgelewerdheid aan die geskiedenis. Mense raak bewus van hulle totale afhanklikheid. Selfbewussyn is die gevoel van volstrekte afhanklikheid. Die bewussyn ten opsigte van God (gottglaubige Selbstbewußtsein) is die strewe na vryheid, oneindigheid, verlossing en die verkryging daarvan lê buite die syn van die mensheid. In hierdie sin is die woord "God" getuienis van die mens se eindigheid. Hier lê die oorsprong van die mens se mitiese en antropomorfe/theriomorfe spreke oor God. ${ }^{4}$ Die "onmiddellike bewussyn van die eindige self" is die bewussyn van die mens as historiese objek wat alleen in taal en geskiedenis aanwesig is. Mitiese spreke oor God is die gevolg van die verskyning van God as 'n "historiese objek", terwyl taal nie daarvoor voorsiening maak om God wat geen objek is nie, tot "taligheid", of te wel "kommunikasie", of te wel "Woord" (Sprachlichkeit), te bring

${ }^{4}$ Carl Jung ([1956] 1967:21) verwys soos volg hierna: "Everything was conceived anthropomorphically or theriomorphically, in the likeness of man or beast ....Thus there arose a picture of the universe which was completely removed from reality, but which correspond exactly to man's subjective fantasies." 
nie. Dit is waaom Schleiermacher die begrip Gefühl gebruik om te verwys na die mens se bestaan coram Deo.

Die woord Gefühl het algemeen voorgekom in die gesprekke van die sogenoemde "intellektuele godsdiensveragters" van die agtiende-negentiende eeu wat die rasionalisme met die estetika wou temper. ${ }^{5}$ Hierdie veragting van die godsdiens het na bewering voortgespruit uit 'n voortbou op die "transendentale kritiek" van Immanuel Kant - 'n bewering wat nie aan die Kantiaanse revolusie reg laat geskied nie! Kant beskryf die vermeende onbeperkte vermoë van Godskennis as "dogmatisme" en as gevolg van die kombinasie van rede en waarneming ontken hy dat God deur abstrakte "proposisies" geken kan word. Dit lei tot die insig in die dialektiese teologie dat God nie geobjektiveer kan word nie en tot die opvatting van die estetika dat selfverwesenliking in kuns en musiek gesoek word.

Schleiermacher onderskei die begrippe "gevoel" en "emosie" (kyk Brandt 1941:105-130). Emosie word deur die ontmoeting met objekte gewek, is derhalwe eindig, kortstondig en wisselend. Gevoel is die bewussyn van eindigheid, is konstant en kom van buite die vermoë van die denkende en willende mens. "Gevoel" is 'n responderende ervaring. Vir Schleiermacher is teologie die refleksie op die mens se godsdienstige bewussyn, die gevoel van absolute afhanklikheid wat nie 'n geobjektiveerde bewussyn is nie. Gottglaubige Bewußtsein is 'n begrip wat beide op die eindige self en die oneindige God reflekteer en word altyd in 'n gegewe geloofsgemeenskap gelokaliseer. Die

\footnotetext{
${ }^{5}$ Dit is binne hierdie konteks waar die invlloed van die Romantiek op die denke van Schleiermacher, asook sy kritiese posisie ten opsigte daarvan raakgesien behoort te word (kyk Van Aarde 1999:11-27). Eksponente van die Aufklärung (bv G L Bauer) het mites, legendes en sages beskou as uitdrukkings van "primitiewe" religiositeit wat nie as basis vir geloof kon dien nie. Hierteenoor hou die Romantiek, literatuurhistories gesien, verband met die oud Franse woord romanz (escrire) wat sedert die Middeleeue na die "roman" as literatuurvorm verwys. Dit het betrekking op daardie tipe vertelling wat doelbewus nie 'n weergawe van 'n werklike gebeure is nie; dit wil sê, 'n novelle. "Waarheid" was nie meer net gevind in proposisies of diskoerse wat met die empiriese "werklikheid" sou ooreenstem nie. Waarheid was eerder met die "irrasionele" ( $d$ w s in die ervaring van geloof as gawe van buite die menslike natuur) verbind. Mites is 'n soort beeldspraak wat ook getuienis kan wees van outentieke bestaan. Die Romantiek as beweging het dus daartoe aanleiding gegee dat eksegete en teoloë nie net in die Bybel sprokies, mites, sages en legendes begin raaksien het nie, maar ook hierdie literatuurvorme (Gattungen) gesien het as "objektiverende spreke" waarin mense se eksistensie as gelowiges uitgedruk word.
} 
"gevoel van absolute afhanklikheid" is 'n responderende ervaring binne die "ekklesiale" ruimte waar die kerugmatiese gebeure plaasvind. Hierdie gebeure word moontlik gemaak deur die "grammatikale" en "psigologiese" hermeneutiek van die Bybel waardeur dit duidelik word dat die taalgebeure in die Bybel "refleksiewe" getuienis is van mense se bevryding van beperktheid, van sonde, as gevolg van die verlossingsgebeure in en deur Jesus Christus.

'n Christelike teologie kan volgens Schleiermacher nie anders as om die begrippe "sonde" en "verlossing" in ag te neem nie. Hierdie twee begrippe hou verband met ons verstaan van die historiese Jesus. Jesus moet nie net as "stigter" (die "inisieerder") van die Christelike geloofsgemeenskap gesien word nie, maar ook as die "determinant" - met ander woorde die bevryding van sonde is deur Jesus self beslissend geleef. Die antitese sonde-verlossing vorm die christliche Selbtbewußtsein. Hierdie "teo-antropologie" verteenwoordig die essensie van die Reformatoriese erfenis van die Westerse Christelike tradisie.

In Schleiermacher se ou-Kersaandgesprek (Die Weinacgtsfeier: Ein Gespräch) word die spanning tussen die vraag na die historiese Jesus en die konvensionele dogma rondom die menswording van Jesus ingetrek in 'n fiktiewe familiegesprek op 'n ou-Kersaand. In die kommentaar wat later, nadat 'n vertaling van die hele werk vanuit Gotiese Duits in Afrikaans in meerdere artikels aangebied is, sal die teoretiese uiteensetting van die hermeneutiese program van Schleiermacher hierbo aan die hand van sy ou-Kersaandgesprek geïllustreer word. In die onderhawige artikel word ' $n$ vertaling van die eerste gedeelte van die "gesprek" gepubliseer en die artikel eindig met opmerkings oor die agtergrond van die skrywe van die ou-Kersaandgesprek. 


\section{3. 'N VERTALING IN AFRIKAANS VAN DIE WEINACHTS- FEIER: EIN GESPRÄCH ${ }^{6}$}

Die aantreklike helder [ontvangs]saal [in die huis] ${ }^{7}$ was feestelik versier, die blomme [in die bakke by al die vensters [in die huis] is na die saal gebring. Die gordyne is egter nie laat sak nie, sodat die sneeu wat duidelik deur die vensters skyn, aan die jaargety sou kan herinner. Al die kopergravure en skilderye wat met die heilige fees verbind kon word, het die mure versier. Van hierdie mooi kunswerke [="Blätter"] was 'n geskenk van die huisvrou aan haar eggenoot. Die talryke ligte ${ }^{8}$ [="hochgestellten Lichter"] het deur hulle deurskynende (lamp)kappe 'n feestelike lig versprei. Dit het tegelykertyd die nuuskierigheid skalks geprikkel, want aan die een kant het dit wel die bekende dinge [in die saal] duidelik genoeg uitgewys, maar aan die ander kant kon die vreemde en nuwe dinge net stadig en by nadere betragting uitgemaak en (met sekerheid) waardeer word.

So wou die opgeruimde en verstandige Ernestine dit gehad het. Sy wou hê dat die deels vrolike [=grappige] en deels ernstige ongeduld net baie stadig bevredig word en dat die klein bont geskenkies nog 'n rukkie lank deur skemer omhul en [so] groter gemaak word.

Die mans en vroue, die seuns en dogters - almal wat deel van die hegte kring was - het hierdie keer vir haar gevra om elke persoon se geskenkies waarmee hulle mekaar wou verbly, so te rangskik dat dit wat andersins onbeduidend sou lyk, beduidend as deel van 'n geheel sal vertoon. Hierin het sy [Ernestine] geslaag. Net soos 'n mens in 'n wintertuin die klein blommetjies van

\footnotetext{
${ }^{6}$ Hierdie vertaling is van 'n deel in die 2 de Duitse uitgawe wat met 'n voorwoord deur Schleiermacher in November 1827 ingelei is, Die teks is in 1843 in Gotiese Duits herdruk. In hierdie artikel word ' $n$ vertaling aangebied van bladsye 465 tot middel 472 . In opvolgende artikels sal 'n vertaling van die res verskyn.

7 Woorde en frases in vierkante hakies kom nie in die oorspronklike Duits voor nie en is deur my as vertaler ingevoeg ter wille van 'n óf meer vloeiende óf duideliker Afrikaans. As die invoegsel in die vierkante hakie met 'n gelykaanteken (=) ingelei is, dui dit op óf die oorspronklike Duits óf 'n meer letterlike Afrikaanse vertaalekwivalent van die oorspronklike Duits. Wanneer ' $n$ uitdrukking in die Afrikaanse vertaling deur 'n skuinsstreep (/) en 'n ander Afrikaanse uitdrukking opgevolg word, het die oorspronklike Duits myns insiens 'n bewuste intertekstuele konnotasie van óf 'n ambivalente en ambigieuse betekenis óf woordspel.

${ }^{8}$ Dit kan beteken dat hulle helder geskyn het of dat hulle hoog gestaan het.
} 
die Galanthus of die viooltjies onder die sneeu of onder die beskermende kombers van mos moet uithaal tussen die immergroen struike, so was elkeen se eie plek [aan die eettafel in die saal] deur klimop, mirt en amarante [=plante] afgegrens. Net so is die sierlikste/breekbaarste (geskenke) onder wit tafeldoeke of bont linne weggesteek, terwy] die groter geskenke óf in die saal óf onder die groot tafels gesoek moes word. Die name [van gaste] is met eetbare versiersel [="Kleinigkeiten] op die omhulsels [geskenkpapier?] geskryf en elkeen moes dan vastel wie die skenker agter elke geskenk was. Die geselskap het in die aangrensende kamers gewag. Almal was opgeruimd en het mekaar geterg. Tog was ongeduld duidelik speurbaar. Onder die voorwendsel om te raai of te verraai, is geskenke uitgedink wat aan iemand duidelik gekoppel kon word vanweë geringe foutjies en gewoontes, grappige gebeurtenisse en lagwekkende misverstande of verleenthede. Diegene wat so moes deurloop, het nie versuim om dieselfde aan ander te doen nie.

Net die klein Sofie was maar stil en het met groot treetjies op en af geloop. In haar onrustige eenvoud was sy in die pad van diegene wat moedswillig heen en weer geloop en oor en weer gepraat het - maar hulle het haar ook gehinder. Uiteindelik het Anton haar met geveinsde misnoë/besorgdheid gevra of sy nie graag al haar geskenke sou wou prysgee in ruil vir 'n towerspieël wat dit vir haar moontlik sou maak om deur die geslote deure te sien nie. Sy het hom geantwoord dat sy in elk geval, eerder as hy, dit sou doen [dit wil sê om haar geskenke prys te gee], want hy is beslis [in vergelyking met haar] meer selfsugtig as wat hy nuuskierig is en buitendien glo hy dat die strale van sy wonderlike verstand nie deur enige muur gestuit kan word nie. Sy het toe in die donkerste hoek gaan sit en haar kop wat sy in haar hande gehou het, nadenkend heen en weer geskud.

Nie lank daarna nie het Ernestine die deur [van die ontvangsaal] oopgemaak, daar bly staan en [toe] teen die deur geleun. 'n Mens sou verwag het dat die vrolike klomp hulle begerig na die vol tafels sou haas, maar hulle het in die middel van die saal, waarvandaan 'n mens alles goed kon sien, omgedraai en spontaan [onwillekeurig] na haar [Ernestine] gekyk. Die plasing [rangskikking] 
[van alles in die saal] was so aantreklik en het so volkome haar teenwoordigheid uitgedruk [="Ausdruckt ihres Sinnes"] dat sy almal se gevoel [="Gefühl"] en oë onwillekeurig en noodgedwonge op haar laat verenig het. Sy het in die halfdonker gestaan en wou haar onopgemerk aan haar geliefdes en aan die duidelike [="leichten"=ligte] vreugde verbly. Die teendeel het egter gebeur. Almal het eers haar geniet [=aan haar verheug]. So asof die geskenke [="das Übrige"] reeds uitgedeel was en sy die skenker van alles was, het hulle rondom haar kom staan. Die kind [Sofie] het haar om haar knieë gevat en met groot oë na haar gekyk - sonder om te glimlag, maar oneindig lieftallig. Die vriendinne [Agnes, Karoline en Friederike] het haar omhels. Eduard het haar op haar mooi halfgeslote oog gesoen en, soos dit vir almal betaam het, het hulle hulle liefde vir haar betuig en laat verstaan dat sy hulle aandag het [hulle aandag aan haar betuig].

Sy moes toe self die teken gee dat hulle die geskenke kon ontvang. Sy het vir hulle gesê: "My geliefdes, as julle my wil bedank dat ek die fees vir julle voorberei het, moet nie dat die mooi raam julle aandag van die skildery [portret] aftrek nie. Hou in gedagte dat ek bloot die feestelike dag, julle vrolike liefde en die [geskenke as] bewyse daarvan, [en] wat julle aan my [tydens die voorbereiding van die fees] toevertrou het, met eer hanteer het. Kom nou, elkeen moet nou maar kom kyk wat hy [of sy] gekry het en wie nie slim genoeg is om te raai nie, moet maar gedweë verduur dat hy [en sy] gespot word."

Aan die spot was daar geen tekort nie. Die vroue en dogters het wel met groot oortuiging by elke geskenk die naam van die skenker uitgeroep, sodat niemand homself [en haarself] kon verskoon nie [="keiner verläugnen"]. Die mans [Anton, Eduard, Leonhardt en Ernst] het egter dikwels verkeerd geraai. Niks was grappiger en vir die mans meer verdrietig wanneer hulle by die reeds verkeerde raaiskoot ook nog 'n grappige gedagte toegevoeg is en soos ' $n$ ongeldige geldwissel onder protes teruggestuur is nie.

"Dit behoort seker so te wees," het Leonhardt gesê, "dat - ofskoon dit ons tereg verdrietig maak - die vroue in hierdie liefdevolle kleinighede ons met hulle skerpsinnigheid oortref. Die waarde [="Bedeutung"] van die geskenke van vroue 
is ' $n$ bewys van die fyn sorg wat hulle daaraan gee. Ook in hierdie verband oortref hulle die gawes van mans. En, soos ons mans hierdie mooi vrug van hulle talent geniet, so moet ons hierdie ander effek maar verduur, hoewel dit ons 'n bietjie in die skadu stel." "Dit is baie vriendelik van jou", het Friederike geantwoord, dit is egter nie eintlik ons talent alleen nie, maar - as ek dit mag sê - 'n bepaalde lompheid wat eie aan julle mans is, wat vir ons tot voordeel strek. Julle is baie gesteld op deurdagte [="geraden"=reguit] weë, soos dit by maghebbers hoort. En julle handelinge - ook as julle niks in die besonder daarmee wil uitdruk nie - is van so 'n verradelike redelikheid [=“Verständlichkeit”], soos byvoorbeeld dié van 'n skaakspeler wat dit nie kan nalaat om sy teenstander se figure wat hy meen in aanvalbare swak posisies is [=onder verdenking is], doelbewus op die skaakbord aan te raak en dan met onrype besluit sy eie skaakfigure ses keer optel voordat hy een enkele skuif maak."

"Ja, ja," het Ernst eerlik glimlaggend en met 'n geveinsde sug geantwoord. "Dit bly sekerlik waar wat die ou Salomo gesê het: 'God het die man opreg geskape, maar vroue maak gebruik van baie vindigryke idees[=kunste] ${ }^{9}$."'

"So het julle dan die troos," het Karoline gesê, "dat julle ons nie bederf het met moderne ordentlikheid nie. Dit is tog dalk so dat beide [mans en vroue] ewig en noodsaaklik is. En as [aan die een kant] julle eerlike naïwiteit [om te beweer dat "God mans opreg geskape het"] die voorwaarde is vir ons slimheid [om na bewering "met pretensies deur die lewe te gaan"], so wees gerus dat, aan die ander kant, ons beperktheid in dieselfde verhouding staan tot julle groter talent."

Intussen is alle geskenke van naby betrag en veral daardie [geskenke] wat eie aan vroue was - soos borduurwerk en fyn naaikuns - is deur almal met kunskennis waarderend beskou [=getoets/ondersoek en geprys].

Sofie het eers net vlugtig na haar eie skatte gekyk, en het dadelik hiernatoe en daarnatoe - na almal gegaan, alles nuuskierig betrag en

${ }_{9}$ Die Duitse woord "Künste" kan, net soos in Afrikaans, onder andere verwys na die "kunste van 'n goëlaar" (dit wil sê in pejoratiewe sin as "pretensieus" - die teendeel van "opregtheid") of in affektiewe sin as verwysend na die "vermoë om wat in die gees lewe op so 'n wyse tot uitdrukking te bring dat dit ontroer, meeskep") (Odendal et al [1965] 1988:625). 
entoesiasties geprys. Sy het egter veral die baie brokkies (soetigheid) van die gebreekte name [wat op die omhulsels van die geskenke was] gebedel. Want sy kon nie genoeg kry van die soetighede nie en het daarvan gehou om baie [=groot voorrade] daarvan bymekaar te maak - veral as sy dit op hierdie manier kon kry. Eers nadat sy haar besittings met sulke voorraad kon meer maak, het sy begin om haar (eie) geskenke van naderby te bekyk. En dan het sy weer van die een na die ander gegaan en elke stuk (afsonderlik) triomfantelik gewys en - as sy dit kon doen - het sy dadelik die geskenk begin gebruik om daarmee die voortreflikheid daarvan die beste te bewys.

"Maar die beste sien jy blykbaar nie raak nie," het haar moeder haar herinner.

"Natuurlik, my enigste moeder," het die kind gesê, "maar ek het nog nie die moed daarvoor gehad nie. Want dit is 'n boek. Dit is nie vir my sinvol as ek nou deur die boek blaai nie. Ek moet hierna myself in my kamertjie toesluit om dit eers daar te geniet. Maar as iemand vir my - en ek is oortuig dat dit nie u was nie - vir my skertsend maar met erns [="ersthaften Scherz"] patrone en instruksies vir brei- en borduurwerk asook ander lekker dinge gegee het, belowe ek in alle erns dat ek dit in die nuwe jaar ywerig sal gebruik. Maar op hierdie oomblik wil ek nog nie weet wat dit [watter soort boek dit] is nie."

"Verkeerd geraai", het die vader gesê, "dit is niks van hierdie aard nie [met ander woorde 'n boek nie], want so iets wil jy nie noual hê nie. Buitendien is dit ook nie 'n boek waarmee jy nou na jou kamer kan terugtrek om dit - soos 'n mens met boeke doen - daar te geniet nie."

Sy het toe dit baie gretig te voorskyn gebring - al het sy gevaar geloop om 'n groot deel van haar soet voorrade te laat val [verlore laat gaan] - en van blydskap uitgeroep: "Musiek!" Sy het deur die bladmusiek geblaai en weer gesê: "O, grote musiek! Kersfees vir 'n hele lewe! Nou gaan julle die mooiste liedere [="Sachen"= stukke=dinge] sing!" Toe het sy die opskrifte van die grootendeels godsdienstige komposisies begin lees - almal het betrekking gehad op die líeflike fees; almal was uniek [="lauter vorzügliche"=besonders] en 'n [ander] deel het [weer] uit seldsame ou stukke [="alte seltene Sachen"] bestaan. Sonder versuim 
het sy na haar vader geloop om sy gesig in geesdriftige dankbaarheid met soene te bedek.

Die kind het nie gehou van [tipiese] vroulike "kunsvlyt" [="weibliche Arbeiten", byvoorbeeld naaldwerk] nie, maar het 'n besliste talent vir musiek getoon - wat ewe beperk as groot was. Hierdie smaak [="Sinn"] was nie beperk nie; inteendeel, sy ervaar hartelike vreugde in alles wat op elke gebied van hierdie kuns [=musiek] mooi is. Maar self wou sy nie dit sing wat in die "groot styl van die kerk" gekomponeer is nie. Soms kon 'n mens dit as 'n teken van 'n blote vrolike stemming sien wanneer sy saggies [="halblaut"] 'n ligte vrolike deuntjie gesing ([="trillern=die stem laat tril] het. As sy deur 'n instrument begelei word ${ }^{10}$ en haar stem - wat reeds al na 'n dieper stem (Alt) neig - behoorlik in beweging bring, sing sy egter net hoog aangeskrewe musiek [="große Gattung"=musiek getoonset in kerkstyl]. Sy weet dan ook hoe om aan elke toon reg te laat geskied en dit is vir elke toon feitlik onmoontlik om losgemaak te word van hierdie liefde [elke toon is deur liefde met die ander verbind], maar nogtans is elke toon selfstandig in presiese [="gemessener"] krag totdat dit weer - soos dit ook met 'n innige soen die geval is - plek aan 'n ander afstaan. Ook wanneer sy alleen [dit wil sê sonder begeleiding] oefen, toon haar sang soveel respek vir die ander stemme - so asof hulle werklik ook gehoor word. Ook wanneer sy soms emosioneel raak, word die harmonie (van die geheel) nooit deur enige oormaat benadeel nie. 'n Mens kan dit ook anders uitdruk. Afgesien van die [liedere] se temas [="Gegenstände"], sing sy met oorgawe [=“Andacht"] en elke toon word met deemoedige [="demüthiger"=groot nederigheid] liefde versorg. Omdat Kersfees eintlik ' $\mathrm{n}$ fees vir kinders is, en sy haar sterk [="ganz besonders"] daarin uitleef, kon daar vir haar geen liefliker geskenk gewees het as hierdie nie.

Sy het 'n tydlank daar gesit en aandagtig na die note gekyk, die akkoorde met haar vingers op die boek [bladmusiek] gespeel en het in haar hart [=binneste] klankloos gesing, maar met opvallende beweging van spiere en lewendige gebare.

${ }^{10}$ Die uitdrukking "Geht sie aber ans Instrument" kan ook verstaan word dat sy self die instrument speel. 
Toe het sy plotseling uit [na buite die saal] gespring, maar gou weer teruggekom en gesê: "Laat staan tog nou al julle betragtings en gesprekke en wees my gaste daar oorkant. Ek het alles [die kerse] aangesteek; die tee sal binnekort gereed wees; die tyd het gekom. Ek is verbied om vir julle iets te skenk - soos julle weet en gesien het - maar ek is nie verbied om julle uit te nooi na 'n uitvoering [="Schauspiel"] nie.

Daar was aan haar ' $n$ voorwaarde gestel. Sy kon een van die skenkers [van geskenke] wees as sy 'n fyn foutlose naaldwerk [="Arbeit"] as 'n eerste geskenk daar kon stel. Sy kon egter dit nog nie regkry nie, maar sy wou tog op die een of ander wyse haar fout reg stel [="schadlos halten"]. Sy het een van daardie klein kunstig vervaardigde speelmeganismes [="Spielwerke"] gehad wat eitlik bedoel is om met klein beweegbare gesnede beeldjies die Kersverhaal teen 'n gepaste agtergrond uit te beeld. Gewoonlik word die oorspronklike doel egter verdring deur 'n aantal bykomstighede wat nie daarby hoort nie; ja, wat selfs in 'n sekere sin opgesmuk [="abgeschmackt"] en plat is, en wat bygevoeg is om aan die eenvoudige meganisme so veel as moontlik kleurvolle tonele te verskaf. Hierdie speelmeganisme het sy skoon gemaak, weer in 'n werkende toestand gebring, hier en daar verbeteringe aangebring en nou staan dit in haar kamer op ' $n$ prominente plek en is verlig.

Op die redelike groot tafelblad [van die speelmeganisme] kon 'n mens met behulp van 'n bietjie verbeelding tussen die deurmekaar rangskikking van 'n paar alledaagse tonele, baie (van die) belangrike episodes van die Christendom uitgebeeld sien. In onsistematiese volgorde het 'n mens die doop van Jesus Christus gesien, Golgotha, die berg van die hemelvaart, die uitstorting van die Heilige Gees, die vernietiging van die tempel, Christene wat teen die Sarasene ${ }^{11}$ veg oor die besit van die Heilige Graf [in Jerusalem], die pous tydens 'n prosessie na die St Peters Katedraal, die brandstapel van Huß en die verbranding van die pouslike bul deur Luther, die doop van die Sakse, die bekerings in Groenland en die bekering van die Negers, die begraafplaas van die Morawiërs (Herrnhuter), die weeshuis van Halle. Dit lyk asof die vervaardiger

11 'n Benaming wat Middeleeuse skrywers vir Moslems in Sirië en Palestina gebruik het. 
[van die speelmeganisme] hierdie weeshuis voorop wou plaas as die mees onlangse uitnemende werk van 'n religieuse begeestering.

Met besondere ywer het die jong meisie water en vuur oralsoor daargestel en so aan die strydende elemente reg laat geskied [goed uitgebeeld]. Die riviere het werklik gevloei en die vuur het gebrand en sy het net geweet hoe om die vlamme aan die brand te hou. Tussen al hierdie dominante voorwerpe het 'n mens lank en selfs tevergeefs na die "geboorte" [van Jesus] gesoek want sy het die ster op 'n slim manier [="weislich"] weggesteek. 'n Mens moes die engele en die herders - wat ook langs 'n vuur gesit het - volg, 'n deur in die muur van die speelmeganisme oopmaak (die huis was net as 'n dekorasie op die muur uitgebeeld) en dan sien jy die heilige familie in 'n vertrek wat eintlik aan die buitekant is. In die arm hut is dit donker; net 'n verskuilde skerp lig skyn helder op die kop van die kindjie [Jesus] en word op die gesig van die moeder [Maria] wat vooroorbuig, weerkaats. In vergelyking met die helder vlamme buite is hierdie sagte glans soos hemelse vuur teenoor aardse vuur.

Sofie het dit hoogs tevrede as haar beste kunswerk geprys. Sy het haarself as ' $n$ tweede Correggio beskou en het haar uitvoering in geheimsinnigheid gehul. Sy het gesê dat sy egter tot nou toe tevergeefs probeer het om die skyn van 'n reënboog toe te voeg omdat, het sy gesê, dat (net) Christene werklik die waarborg is dat lewe en plesier in die wêreld nooit sal vergaan nie. Sy het 'n paar oomblikke voor haar kunswerk gekniel - haar kop net bokant die tafelblad - en het onverpoosd in die vertrek gekyk. Skielik het sy daarvan bewus geword dat haar moeder direk agter haar staan. Sonder om van houding te verander, het sy haar kop gedraai en het bewoë gesê: "O, Moeder, u kon net so wel die gelukkige moeder van die goddelike kind wees! Maak dit u nie hartseer dat u dit nie is nie? En is dit nie die waarom moeders hulle seuns meer [as vir hulle dogters] lief het nie? Maar dink aan die heilige vroue wat Jesus begelei het en aan alles wat u vir my van hulle vertel het. Ek wil verseker ook so ['n vrou/moeder] word soos u." Die bewoë moeder het haar opgetel en gesoen. 


\section{AGTERGROND VAN DIE OU-KERSAANDGESPREK (DIE WEINACHTSFEIER)}

'n Vriendin van Schleiermacher was klaarblyklik die stimulus agter die skrywe van die dialoog Die Weinachtsfeier wat bedoel was as 'n Kersgeskenk vir sy vriende. Dit is een van die belangrikste werke van Schleiermacher der Kirchenvater des 19.Jarhhunderts (Barth 1972:425). Volgens Keith Clements (1987:195) is hierdie werk "one of the most humanly charming pieces of serious theology ever written, as it vividly portrays young and old, men and women, sceptic and pietist, enjoying music and conversation and sharing their thoughts on the significance of the joy of the Christmas season." Dit is 'n werk wat nie verstaan kan word as Schleiermacher se sensitiwiteit vir wat vrou-wees as "identiteit van syn" is, nie ingesien word nie. Sy siening oor vroue het aandag gekry in verskillende werke. Sy ou-Kersaandgesprek is in hierdie opsig waarskynlik die belangrikste.

Die skrywer as verteller assosieer homself nie met die vertelde karakters wat óf die kliniese rasionalisme van die liberale teologie óf die rigiede ortodoksie verteenwoordig nie. In hierdie teks kry ons 'n voorbeeld van hoe Schleiermacher die konsep "godsdiens as ' $n$ absolute afhanklikheidsgevoel" in sowel 'n historieskritiese as 'n kerklike konteks verstaan. Drucilla Richardson (1991:133-164) het op grond van haar studie van hierdie werk (asook van onder andere Vertraute Briefe über Friedrich Schlegels Lucinde, waarin Schleiermacher ([1846] 1907:421-506) respondeer op die idees van sy Berlynse kunstenaarsvriend en digter, Friedrich Schlegel - kyk Clements 1987:19-22) interessante afleidings gemaak. Sy toon aan dat Schleiermacher die terme Anschauung ("denke" - 'n begrip wat uitruilbaar is met Kant se "teoretiese rede") as 'n bewuste manlike Geschlechtscharakter en Gefühl (geloof as absolue afhanklikheid van God - 'n begrip wat hoort tot Kant se "praktiese rede") as 'n bewuste vroulike Geschlechtscharakter gebruik. Hiermee het Schleiermacher in 'n sekere sin die totale agtiende-eeuse (eintlik die hele voorafgaande agrariese periode se) etiek herdefinieer deur die begrip "kuisheid" (Schamhaftigkeit) anders te gebruik. Vir hom het dit nie meer betrekking op "preutse kuisheid" wat 'n spesiale eienskap 
van slegs die vroulike geslag sou wees nie. Schleiermacher gebruik die term in die sin van respek vir die vryheid van ander mense, 'n sensitiwiteit vir hulle broosheid, en dit karakteriseer beide geslagte in hulle onderlinge sosiale interaksie.

Schleiermacher was daarvoor bekend dat hy vriendskap en intelektuele gesprek nie net met mans nagestreef het nie, maar ook met vroue. Onder hulle was veral sy suster Charlotte von Kathen, die getroude Jodin Henriette Herz en Eleonore Grunow, die vrou van 'n Berlynse pastor. Henriette Herz was sy mees intieme vertroueling. Beide het ten spyte van skinder hulle "geestelike en intellektuele vriendskap" (Clements 1987:21) nie geheim gehou nie (kyk Schleiermacher [1860] 1860:159, 318). Die verhouding tussen Schleiermacher en Eleonore het egter meer as net intellektuele geneëntheid vir meklaar ingehou en dit het meegebring dat hy op 'n stadium nie die konvensionele siening oor die huwelik gedeel het nie. Eleonore wou egter nie van haar man skei nie en die aard van die vriendskap het verander. In 'n brief aan Leonore in 1802 skryf Schleiermacher "want dit is op grond van die insig in die hart en gesindheid van vroue dat ek geleer het wat waaragtig waarde het" (kyk Clements 1987:21). Aan sy suster Charlotte skryf hy: "wanneer ek ook al my gemoedelik verlustig aan 'n onmoontlike wens, dan verlang ek om 'n vrou te wees" (kyk Schleiermacher 1860:382). Oor hierdie opmerking sê Keith Clements (1987:22): "The reason Schleiermacher gives for this fantasy, however, should be noted. It is the opportunity, as he sees it, for women to retain inner feelings of love and imagination as compared with men who are so quickly lost and occupied in activity."

Clements (1987:26) verwys soos volg na die waarskynlike aanleidende rede vir die skryf van die ou-Kersaandgesprek: "On the personal level, it was during this time that Eleonore Crunow finally declined to separate from her husband. Passion, then, did not always have the last word in the face of social convention. Some have seen in her refusal one of the stimuli behind the relatively short Christmas Eve ...." 
Volgens Wilhelm Dilthey (1879/1880:343-345; 1922:765-767) was Schleiermacher se ou-Kersaandgesprek ongetwyfeld deur sy studie van Plato beïnvloed. Die gesprek vind plaas in die byeenkoms van 'n middelklas Duitse familie wat saam met vriende ou-Kersaand vier. Eduard en Ernestine is die ouers en onder die kinders is dit veral die dogter Sofie wat met haar godsdienstigheid en musikaliteit die gaste se aandag trek. Onder hulle is daar die verloofde paar Ernst en Friederike, 'n jong eggenote Agnes en 'n ouere vrou Karoline. In kontras met hulle almal is daar die regsgeleerde Leonhardt wat met sy kritiese rasionalisme die rol van duiwelsadvokaat speel. Op die laaste twee bladsye van die boek vind ons 'n sekere Josef. Hy word nie eintlik gekarakteriseer nie, maar hy praat die laaste. Wat hy sê, vorm volgens Karl Barth (1982:58) Schleiermacher se selfportret (vgl ook Webster 2000: 36-39).

Die gesprek is besonder goed gestruktureer. Die dekor van die familiefeesviering kom eerste aan die orde: die uitdeel van geskenke en die saamsing vorm 'n kleinskaal model van die Kersverhaal en help bydra om 'n Kersfeesstemming te skep. Amper asof dit so behoort te wees, neem die "wonderkind" Sofie die voorgrondrol in. Sy het deurdagte idees, speel klavier en gee aanleiding dat die volwassenes kan gesels oor die grootmaak van kinders, geloofsonderrig, die rol van die kerk, kuns, die interaksie tussen geslagte vreugde en pyn. Op die versoek van die mans begin Ernestine, Agnes en Karoline om hulle vroeëre ervarings van ou-Kersaandvierings te vertel. Terwyl Friederike klavier speel, reageer die mans Lenonhardt (die rasionalis), Ernst (stil en introverties) en Eduard (die spekulatiewe mistikus). Hulle reaksies op die vroue se bydraes vorm die derde en waarskynlik belangrikte deel van die gesprek. Volgens Karl Barth (1982:58) vertoon die mans se reaksies 'n meer diadakties-teoretiese en teologiese vorm as dié van die vroue in die verhaal. Hierdie uitspraak is egter aanvegbaar, soos daar later in die kommentaar aangetoon sal word.

Uiteindelik kom die langverwagte Josef op die toneel. Hy staan die ander mans se vorm van gesprek teë en wil die geleentheid eerder vul met "vreugde wat nie verwoord kan word nie" omdat dit gewek word deur 'n "subjek wat nie 
verwoord kan word nie". Die einde van die gesprek bring die gesprek terug na waar dit begin het: "Kom dan en bring veral die kind [Sofie] as sý nog nie slaap nie en laat my die mooi dinge van julle sien en laat ons bly wees en iets godsdienstig en vreugdevol sing!"

\section{Literatuurverwysings}

Barth, K [1952] 1972. Protestant theology in the nineteenth century: Its background \& history, tr by J Bowden. London: SCM.

Barth, K 1982. The theology of Schleiermacher: Lectures at Gottingen, winter semester of 1923/4, edited by D Ritschl and translated by G W Bromiley. Edinburgh: T\&T Clark.

Birker, H-J, Ebeling, G, Fischer, H, Kimmerle, H \& Selge, K-V (Hrsgs) 1980. Friedrich Schleiermacher Kritische Gesamtsausgabe, Band 1. Berlin: De Gruyter.

Birker, H-J, Ebeling, G, Fischer, H, Kimmerle, H \& Selge, K-V (Hrsgs) 1980. Friedrich Schleiermacher Kritische Gesamtsausgabe, Band 7, Teilband 1 \& Teilband 2. Berlin: De Gruyter.

Birker, H-J, Ebeling, G, Fischer, H, Kimmerle, H \& Selge, K-V (Hrsgs) 1984. Friedrich Schleiermacher Kritische Gesamtsausgabe, Band 7, Teilband, 3. Berlin: De Gruyter.

Brandt, R 1941. The philosophy of Schleiermacher: The development of his theory of scientific and religious knowledge. Westport, CT: Greenwood Press, Publishers.

Clements, K W 1987. Friedrich Schleiermacher: Pioneer of modern theology. London: Collins. (The Making of Modern Theology.)

Collins, J \& Selina, H [1999] 2001. Introducing Heidegger. Cambridge: Icon Books. Dilthey, W 1879/1880. Die Weinachtsfeier. Westermanns Monatshefte 47, 343-345.

Dilthey, W 1922. Leben Schleiermachers, hrsg H Mulert, 765-767. 2.Auflage. Berlin. Dilthey, W 1924. Die Entstehung der Hermeneutik, in Misch, G (Hrsg), Gesammelte Schriften, 5. Die geistige Welt: Einleitung in die Philosophie des Lebens. Stuttgart: B G Tübner.

Gadamer, H-G 1972. Wahrheit und Methode: Grundzüge einer philosphischen Hermeneutik. 3.Auflage. Tübingen: Mohr (Paul Siebeck).

Hertel, F 1965. Das theologische Denken Schleiermachers. Zürich: Zwingli Verlag. Horner, C \& Westacott, E 2000. Thinking through Philosophy: An introduction. Cambridge: Cambridge University Press.

Jung, C G [1956] 1967. Symbols of transformation: Collected works, vol 5. $2^{\text {nd }}$ edition. Princeton, NJ: Princeton University Press. 
Kimmerle, H [1977] 1986. Editor's introduction, in Schleiermacher, F D E, Hermeneutics: The handwritten manuscripts, edited by $\mathrm{H}$ Kimmerle and translated by J Duke \& J Forstman, 21-40. Atlanta, GA: Scholars Press. (AAR Texts and Translations 1.)

Mueller-Vollmer, K 1992. Foundations: General theory and art of interpretation: Friedrich D E Schleiermacher, in Mueller-Vollmer, K (ed), The hermeneutics reader: Texts of the German tradition from the Enlightenment to the present, $72-$ 97. New York, NY: Continuum.

Odendal, F F et al [1965] 1988. HAT. Verklarende Handwoordeboek van die AfrikaanseTaal. Tweede uitgawe, sewende druk. Johannesburg: PerskorUitgewery.

Palmer, R E 1969. Hermeneutics: Interpretation theory in Schleiermacher, Dilthey, Heidegger, and Gadamer. Evanston: Northwestern University Press. (Northwestern University Studies in Phenomenology \& Existential Philosophy.)

Richardson, D 1991. The role of women in the life and thought of the early Schleiermacher (1768-1806): An historical overview. Lewiston, NY: Edwin Mellen. (Schleiermacher Studies and Translations 7.)

Schleiermacher, F D E [1799] 1958. On religion: Speeches to its cultural despisers, tr by J Oman. New York: Harper \& Bros.

Schleiermacher, F D E [1805] 1843. Die Weinachtsfeier: Ein Gespräch, in Sämmtliche Werke, Erste Abtheilung: Zur Theologie, Erster Band, 461-525. Berlin: G Reimer.

Schleiermacher, F D E [1830] 1928. The Christian faith, translation of the second edition by H R Mackintosh \& J S Stewart. Edinburgh: T \& T Clark.

Schleiermacher, F [1846] 1907. Vertraute Briefe über Friedrich Schlegels Lucinde, in Sämmtliche Werke, 2, Zur Philosofie, I, 421-506, hrsg vom J Fränkel. Jena.

Schleiermacher, F D E [1860] 1860. The life of Schleiermacher as unfolded in his autobiography and letters, Volume 1, tr by F Rowan. London: Smith, Elder and Co.

Schleiermacher, F D E [1977] [1992]. Hermeneutik und Kritik: Mit einem Anhang sprachphilosophischer Texte Schleiermachers, hrsg vom M Frank. Frankfurt a/M: Suhrkamp.

Streetman, R F 1988. Introduction, in Duke, J O \& Streetman, R F (eds), Barth and Schleiermacher: Beyond impasse, 1-8. Philadelphia, PA: Fortress.

Van Aarde, A G 1999. Wat is waarheid? 'n Teologiese antwoord van 'n Bybelwetenskaplike, in Van Wyk, D J C (red), 20 ste eeu Hervormde teologie, 11-27. Pretoria: SENTIK.

Webster, J 2000. Barth. London: Continuum. (Outstanding Christian Thinkers.) 